\title{
Nutrient concentration and nutritional efficiency in 'Gigante' cactus pear submitted to different spacings and fertilizations
}

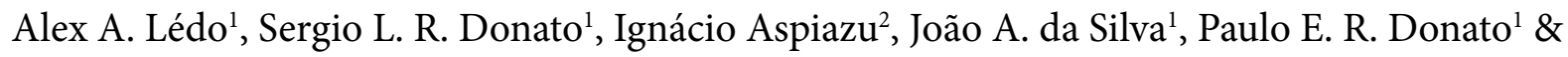 \\ Abner J. de Carvalho \\ ${ }^{1}$ Instituto Federal de Educação, Ciência e Tecnologia Baiano/Setor de Agricultura, Guanambi, BA, Brasil. E-mail: alex.ledo@ifbaiano.edu.br (Corresponding \\ author) - ORCID: 0000-0002-6176-6363; sergio.donato@ifbaiano.edu.br - ORCID: 0000-0002-7719-4662; joao.silva@ifbaiano.edu.br - ORCID: 0000- \\ 0001-5358-356X; paulo.donato@ifbaiano.edu.br - ORCID: 0000-0001-8696-8378 \\ ${ }^{2}$ Universidade Estadual de Montes Claros/Departamento de Ciências Agrárias, Janaúba, MG, Brasil. E-mail: ignacio.aspiazu@unimontes.br - ORCID: \\ 0000-0002-0042-3324; abner.carvalho@unimontes.br - ORCID: 0000-0002-6644-5307
}

\begin{abstract}
The objective of this study was to evaluate nutrient concentration and nutritional efficiency in 'Gigante' cactus pear under different chemical, organic and organomineral fertilizations, planting configurations and spacings, during three production cycles. Seventy two treatments, involving two types of configuration in the plots, three spacings in the subplots and 12 types of fertilization in the sub-subplots were arranged in a split-split-plot scheme, in a randomized block design, with three repetitions. At the time of harvest of each production cycle, 40 cladode tissue samples were collected per treatment to determine dry matter mass and nutrient concentration, which were used to calculate the coefficients of biological utilization of nutrients. Organic fertilization reduces $\mathrm{Mn}$ concentrations in cladodes to levels below the sufficiency range. The nutritional efficiency of N, S, P, Mn and $\mathrm{Zn}$ is higher with organic and organomineral fertilizations and are associated with higher dry matter yields, whereas K nutritional efficiency is higher with mineral fertilization. The absence of fertilization or application of $30 \mathrm{Mg} \mathrm{ha}^{-1}$ year-1 of bovine manure is insufficient to ensure nutritional status and dry matter yield above $15 \mathrm{Mg} \mathrm{ha}^{-1}$ in 'Gigante' cactus pear.
\end{abstract}

Key words: Opuntia sp., biological utilization coefficient, yield

\section{Teores de nutrientes e eficiência nutricional em palma forrageira 'Gigante' sob diferentes adubações e espaçamentos}

\begin{abstract}
RESUMO: Objetivou-se com o presente trabalho avaliar durante três ciclos de produção, os teores de nutrientes e a eficiência nutricional em Palma forrageira 'Gigante' submetida a diferentes adubações química, orgânica e organomineral, configurações de plantio e espaçamentos. Setenta e dois tratamentos, envolvendo dois tipos de arranjos nas parcelas, três espaçamentos nas subparcelas e 12 tipos de adubação nas sub-subparcelas foram dispostos em esquema de parcelas sub-subdivididas, em delineamento experimental em blocos casualizados, com três repetições. Na época da colheita de cada ciclo produtivo, coletaram-se 40 amostras de tecidos dos cladódios por tratamento para determinação da massa de matéria seca e dos teores de nutrientes e a partir destes calcularam-se os coeficientes de utilização biológica dos nutrientes. Verificou-se que a adubação orgânica diminui os teores de Mn nos cladódios abaixo da faixa de suficiência. A eficiência nutricional de N, $\mathrm{P}, \mathrm{S}, \mathrm{Mn}$ e Zn é maior com adubação orgânica e organomineral e estão associadas às maiores produtividades de matéria seca, enquanto de K é maior com adubação mineral. A ausência de adubação ou aplicação de 30 $\mathrm{Mg} \mathrm{ha}^{-1}$ ano $^{-1}$ de esterco bovino é insuficiente para assegurar o estado nutricional e produtividade de matéria seca acima de $15 \mathrm{Mg} \mathrm{ha}^{-1}$ em palma forrageira 'Gigante'.
\end{abstract}

Palavras-chave: Opuntia sp., coeficiente de utilização biológica de nutrientes, produtividade 


\section{INTRODUCTION}

The use of different planting densities (Silva et al., 2014), arrangement or distribution of cactus pear plants in the area (Silva et al., 2012) may alter absorption of nutrients and, consequently, the concentrations of the elements in the cladodes. Likewise, different planting spacings (Cavalcante et al., 2014), use of doses of organic fertilization (Donato et al., 2016), or mineral fertilization (Silva et al., 2012) may affect the nutrient concentrations in the cladodes and the yield of cactus pear.

Chemical analysis of the leaf tissue is important to evaluate the nutritional status of the plants, complementing soil chemical analysis and visual diagnosis, and reflects the nutrient dynamics in the soil-plant system (Donato et al., 2010). However, it requires the definition of standards and critical levels of nutrients for correct interpretation, such as sufficiency ranges (Donato et al., 2017). Interpretative patterns for the nutrient concentrations in Opuntia ficus-indica cladodes were defined by Blanco-Macías et al. (2010) using the BoundaryLine approach for the edaphoclimatic conditions of Mexico and by Alves (2017) through the methods of Mathematical Chance (ChM), sufficiency range and critical level (NCRIz). On the other hand, Donato et al. (2017) established the standards for the chemical attributes of the soil cultivated with 'Gigante' cactus pear by the sufficiency range and NCRIz methods.

Some factors, and especially different types of fertilization such as organic, mineral or organomineral, can influence the nutrient utilization efficiency, a subject with little information on 'Gigante' cactus pear and with difficult establishment of relationships that explain its values in different situations. This assumes greater importance when long-term contribution is considered, due to alterations in the physical, chemical and biological characteristics of the soil, in a perennial crop such as cactus pear.

Thus, the present study aimed to evaluate during three production cycles the concentrations of nutrients and nutritional efficiency in 'Gigante' cactus pear subjected to mineral, organic and organomineral fertilization, planting configurations and spacings.

\section{Material ANd Methods}

The experiment was conducted for three production cycles at the Instituto Federal de Educação, Ciência e Tecnologia da Bahia, Campus of Guanambi, BA, Brazil, in an Oxisol, with weak A horizon, medium texture and on a flat to gently undulating relief. The coordinates of the area are $14^{\circ} 13^{\prime} 30^{\prime \prime}$ $\mathrm{S}, 42^{\circ} 46^{\prime} 53^{\prime \prime} \mathrm{W}$ and altitude of $525 \mathrm{~m}$, and its climate is Aw semiarid, according to Köppen's classification, with average annual precipitation of $680.0 \mathrm{~mm}$ and temperature of $25.9^{\circ} \mathrm{C}$.

In the first production cycle, lasting 650 days from planting to harvesting, conducted between October 2011 and July 2013, the precipitation was $912.27 \mathrm{~mm}$, corresponding to two rainy seasons, between October 2011 and February 2012 (442.67 $\mathrm{mm}$ ) and between October 2012 and April 2013 (469.62 mm). In the second cycle, lasting 330 days between two successive harvests, from August 2013 to July 2014, the precipitation was
$853.96 \mathrm{~mm}$. In the third cycle, lasting 330 days, between August 2014 and July 2015, the precipitation was $879.60 \mathrm{~mm}$. The data were recorded in an automatic weather station installed in the experimental area.

The treatments were arranged in split plots, in a randomized block design, with three repetitions, and consisted of two planting configurations (triple and quadruple rows) in the plots; three spacings: $\mathrm{S}_{1}(3.00 \times 1.00 \times 0.25 \mathrm{~m}) ; \mathrm{S}_{2}(3.00 \times 1.00$ $\mathrm{x} 0.16 \mathrm{~m})$; and $\mathrm{S}_{3}(3.00 \times 1.00 \times 0.125 \mathrm{~m})$, in the subplots, with $24,000,37,500$ and 48,000 plants ha $^{-1}$ for the triple rows and 26,666, 41,666 and 53,333 plants ha ${ }^{-1}$ for the quadruple rows, respectively; and 12 types of manuring $\left(\mathrm{Mg} \mathrm{ha}^{-1}\right) /$ mineral fertilization/- N- $\left.\mathrm{P}_{2} \mathrm{O}_{5}-\mathrm{K}_{2} \mathrm{O}\left(\mathrm{kg} \mathrm{ha}^{-1}\right): 1\right)$ 0-000-000-000;2) $0-300-300-300$; 3) 0-300-300-600; 4) 30-000-000-000; 5) $30-150-300-300$; 6) 30-150-300-600; 7) 60-000-000-000; 8) 60-000-300-300; 9) 60-000-300-600; 10) 90-000-000-000; 11) 90-000-000-300; and 12) 90-000-000-600, in sub-subplots.

Prior to planting, soil samples were collected for chemical and textural characterization: sandy clay loam texture; $\mathrm{pH}$ = 5.57; Organic matter $=1.13 \mathrm{dag} \mathrm{kg}^{-1} ; \mathrm{P}=23.57$ and $\mathrm{K}=$ $181.67 \mathrm{mg} \mathrm{dm}^{-3} ; \mathrm{Na}, \mathrm{Ca}, \mathrm{Mg}$ and $\mathrm{H}+\mathrm{Al}=0.10,1.93,0.87$ and $1.63 \mathrm{cmol}_{\mathrm{c}} \mathrm{dm}^{-3}$, respectively; B, $\mathrm{Zn}, \mathrm{Fe}$ and $\mathrm{Mn}=0.40,0.40$, $2.03,35.93$ and $50.2 \mathrm{mg} \mathrm{dm}^{-3}$, respectively; base saturation, effective CEC and CEC at pH 7.0 $=3.40,3.40$ and $4.97 \mathrm{cmol}_{c}$ $\mathrm{dm}^{-3}$, respectively; $\mathrm{V}=67.67 \%$; Prem $=39.10 \mathrm{mg} \mathrm{L}^{-1}$ and EC $=0.93 \mathrm{dS} \mathrm{m}^{-1}$.

After the preparation of the area, the furrows were opened with furrower of three and four rows regulated to $1.00 \mathrm{~m}$ between furrows and average depth of $0.30 \mathrm{~m}$. Then, the seedlings for planting were collected and left at rest in the shade for ten days, for curing. Planting was performed with one cladode per hole, in the vertical position, with the cut part facing the soil, buried to $50 \%$ of its height.

Invasive plants were controlled with a hoe and herbicide, glyphosate at a dose of $200 \mathrm{~mL} 20 \mathrm{~L}^{-1}$ of water, with two applications in each rainy season, according to Silva et al. (2012; 2013) and Donato et al. (2014a,b).

The fertilizations used at planting followed the treatments with supply of 130-270-75 of $\mathrm{N}-\mathrm{P}_{2} \mathrm{O}_{5}-\mathrm{K}_{2} \mathrm{O}$ applied in the furrow. Subsequently, in the rainy seasons of the respective cycles, topdressing fertilization was performed with the remainder of the doses applied broadcast at $20 \mathrm{~cm}$ from the plants.

Bovine manure doses of 30,60 and $90 \mathrm{Mg} \mathrm{ha}^{-1}$ respectively added to the soil 130-270-75, 260-540-150 and 390-810-225 $\mathrm{kg} \mathrm{ha}^{-1}$ of N-P $\mathrm{P}_{2}-\mathrm{K}_{2} \mathrm{O}$ (Donato et al., 2017). The manure had OM content of $63.73 \mathrm{~g} \mathrm{~kg}^{-1}$, ash content of $36.27 \mathrm{dag} \mathrm{kg}^{-1}$, total carbon content of $29.98 \mathrm{dag} \mathrm{kg}^{-1}$ and $\mathrm{pH} 7.42$ (Brasil, 2014), moisture on dry basis at $65^{\circ} \mathrm{C}$ of $16.72 \%$, contents of macronutrients: $\mathrm{Ca}, \mathrm{Mg}, \mathrm{K}, \mathrm{N}$ and $\mathrm{S}-1.7,0.2,2.5,5.2$ and 2.3 $\mathrm{g} \mathrm{kg}^{-1}$ (EPA 3051/APHA 3120B), in this order, $\mathrm{P}=4.7 \mathrm{~g} \mathrm{~kg}^{-1}$ (APHA 4500-PC); micronutrients (EPA 3051/APHA 3120B): $\mathrm{B}, \mathrm{Cu}, \mathrm{Zn}, \mathrm{Mn}$ and $\mathrm{Fe}-2.1,45.2,200.5,391.8$ and $1,932.4 \mathrm{mg}$ $\mathrm{kg}^{-1}$, respectively; and density of $0.38 \mathrm{~g} \mathrm{~cm}^{-3}$ (Brasil, 2014).

The sources used as mineral fertilizer were: ammonium sulfate, $\left(\mathrm{NH}_{4}\right)_{2} \mathrm{SO}_{4}(20 \% \mathrm{~N} ; 24 \% \mathrm{~S})$, single superphosphate, $\mathrm{Ca}\left(\mathrm{H}_{2} \mathrm{PO}_{4}\right)_{2} 2 \mathrm{H}_{2} \mathrm{O}\left(18 \% \mathrm{P}_{2} \mathrm{O}_{5} ; 12 \% \mathrm{~S} ; 18 \% \mathrm{Ca}\right)$ and potassium chloride, $\mathrm{KCl}\left(58 \% \mathrm{~K}_{2} \mathrm{O} ; 45 \% \mathrm{Cl}\right)$. Nitrogen and potassium were split into two applications, at the beginning and middle 
of the rainy season of each cycle. $\mathrm{P}$ was applied at the time of planting. In all treatments, $1.5 \mathrm{~kg} \mathrm{ha}^{-1}$ of $\mathrm{Zn}$ and $0.5 \mathrm{~kg} \mathrm{ha}^{-1}$ of $\mathrm{B}$ were also applied in the three production cycles in the soil, using the sources zinc sulfate, $\mathrm{ZnSO}_{4}(36 \% \mathrm{Zn})$ and boric acid, $\mathrm{H}_{3} \mathrm{BO}_{3}(17.5 \% \mathrm{~B})$.

In the harvesting period, 40 samples of cladode tissues with approximately $25 \mathrm{~g}$ each were collected per treatment to determine the nutrient concentrations. The samplings considered the repetitions of each treatment and were performed in the three consecutive annual cuts (harvest). All orders of cladodes harvested (primary to quaternary) were sampled using a hole saw with $5.0 \mathrm{~cm}$ diameter and $4.0 \mathrm{~cm}$ depth, adapted to a battery drill, which was turned on above the cladode to remove a circular and uniform slice. The samples were sliced, mixed, weighed until reaching $1.0 \mathrm{~kg}$ of fresh weight and dried in a ventilation oven at $60 \pm 0.2^{\circ} \mathrm{C}$ for $120 \mathrm{~h}$ (Silva et al., 2012; Donato et al., 2016).

The concentrations of macronutrients [ $\mathrm{N}, \mathrm{P}, \mathrm{K}, \mathrm{Ca}, \mathrm{Mg}$ and $\left.\mathrm{S}\left(\mathrm{g} \mathrm{kg}^{-1}\right)\right]$ and micronutrients [B, $\mathrm{Cu}, \mathrm{Fe}, \mathrm{Mn}$ and $\left.\mathrm{Zn}\left(\mathrm{mg} \mathrm{kg}^{-1}\right)\right]$ were determined. The analytical determinations followed Malavolta et al. (1989): N, sulfuric acid digestion with the Kjeldahl method; $\mathrm{P}, \mathrm{K}, \mathrm{S}, \mathrm{Ca}, \mathrm{Mg}, \mathrm{Cu}, \mathrm{Fe}, \mathrm{Mn}, \mathrm{Zn}$ and $\mathrm{Na}$, nitric-perchloric digestion and $\mathrm{B}$, dry digestion.

The biological utilization coefficients of all nutrients $\left(\mathrm{BUC}_{\mathrm{Nui}}\right)$ were determined based on the dry matter weight and concentrations of nutrients in the cladodes of the cactus pear, according to Eqs. 1 and 2, adopted by Deus et al. (2015).

$$
\mathrm{BUC}_{\mathrm{Nui}}=\frac{\mathrm{DMY}}{\mathrm{A}_{(\mathrm{i})}}
$$

where:

$\mathrm{BUC}_{\mathrm{Nui}}$ - biological utilization coefficient of the nutrient i, $\mathrm{kg} \mathrm{kg}^{-1}$;

DMY - dry matter yield, $\mathrm{kg} \mathrm{ha}^{-1}$; and,

$A_{(i)}-$ accumulation of the nutrient i, $\mathrm{kg} \mathrm{ha}^{-1}$, given by Eq. 2:

$$
\mathrm{A}_{(\mathrm{i})}=\mathrm{CN}_{(\mathrm{i})} \times \mathrm{DMY}
$$

where:

$$
\mathrm{CN}_{(\mathrm{i})} \text { - content of the nutrient } \mathrm{i}, \mathrm{kg} \mathrm{kg}^{-1} \text {. }
$$

The data of the evaluated characteristics were subjected to analysis of variance. Significant interactions were further analyzed and, subsequently, the means relative to fertilization were grouped by the Scott-Knott test $(\mathrm{p} \leq 0.05)$ and the means relative to configurations and spacings were compared by $\mathrm{F}$ and Tukey tests $(\mathrm{p}<0.05)$, respectively.

\section{Results AND Discussion}

For the N, S and Mn concentrations evaluated in the cladodes of 'Gigante' cactus pear in the first cycle, there was interaction $(\mathrm{p} \leq 0.05)$ between fertilization and planting configurations, whereas for $\mathrm{S}$ concentrations in the second cycle there was interaction $(\mathrm{p} \leq 0.05)$ between fertilizations and spacings. The concentrations of $\mathrm{P}, \mathrm{K}, \mathrm{Ca}, \mathrm{B}, \mathrm{Cu}, \mathrm{Fe}$ and $\mathrm{Zn}$ in the first cycle and of $\mathrm{N}, \mathrm{P}, \mathrm{K}, \mathrm{Ca}, \mathrm{Fe}, \mathrm{Mg}$ and $\mathrm{Mn}$ in the second and third cycles were influenced by the fertilization ( $\mathrm{p}$ $<0.05)$, regardless of the planting configurations and spacings.

In the first production cycle, for $\mathrm{N}$ concentrations in the cladodes of 'Gigante' cactus pear, two groups were formed by the Scott-Knott criterion ( $\mathrm{p} \leq 0.05)$ between fertilizations, for both configurations. The highest $\mathrm{N}$ concentrations occurred under the mineral fertilizations 0-300-300-300 in the triple row and 0-300-300-300, 0-300-300-600 in the quadruple row and under organomineral fertilizations 30-150-300-300 and 30-150-300-600 of manure $\left(\mathrm{Mg} \mathrm{ha}^{-1}\right)-\mathrm{N}\left(\mathrm{kg} \mathrm{ha}^{-1}\right)-\mathrm{P}_{2} \mathrm{O}_{5}(\mathrm{~kg}$ $\left.\mathrm{ha}^{-1}\right)-\mathrm{K}_{2} \mathrm{O}\left(\mathrm{kg} \mathrm{ha}^{-1}\right)$ in the quadruple row (Table 1). In these fertilizations, the concentrations ranged from 14.2 to $18.4 \mathrm{~g}$ $\mathrm{kg}^{-1}$, within the sufficiency range (13.0-18.9 $\left.\mathrm{g} \mathrm{kg}^{-1}\right)$ proposed by Donato et al. (2017), and close to the $14.7 \mathrm{~g} \mathrm{~kg}^{-1}$ found by Silva et al. (2012), with application of 200-150-100 $\mathrm{kg} \mathrm{ha}^{-1}$ of N-P $\mathrm{O}_{5} \mathrm{O}_{5}^{-}$

\begin{tabular}{|c|c|c|c|c|c|c|}
\hline Cycle I - 2011/2013 & \multicolumn{6}{|c|}{ Concentrations of nutrients } \\
\hline \multirow{4}{*}{ Fertilizations } & \multicolumn{4}{|c|}{ Macronutrients } & \multicolumn{2}{|c|}{ Micronutrient } \\
\hline & \multicolumn{2}{|c|}{$N\left(g_{k g}^{-1}\right)$} & \multicolumn{2}{|c|}{$S\left(g_{k g}^{-1}\right)$} & \multicolumn{2}{|c|}{$\operatorname{Mn}\left(\mathrm{mg} \mathrm{kg}^{-1}\right)$} \\
\hline & \multicolumn{6}{|c|}{ Planting configurations } \\
\hline & Triple row & Quadruple row & Triple row & Quadruple row & Triple row & Quadruple row \\
\hline $0-000-000-000^{*}$ & $12.2 \mathrm{~B} \mathrm{a}$ & $12.7 \mathrm{~B} \mathrm{a}$ & $0.9 \mathrm{~B} \mathrm{a}$ & $0.9 \mathrm{C} \mathrm{a}$ & $218.9 \mathrm{C} \mathrm{a}$ & $231.6 \mathrm{C} \mathrm{a}$ \\
\hline $0-300-300-300$ & $18.4 \mathrm{~A} \mathrm{a}$ & $16.4 \mathrm{~A} \mathrm{a}$ & $3.1 \mathrm{~A} \mathrm{a}$ & $3.9 \mathrm{~A} \mathrm{a}$ & $706.1 \mathrm{~A} \mathrm{~b}$ & $889.4 \mathrm{~A} a$ \\
\hline $0-300-300-600$ & 14.1 B a & $16.3 \mathrm{~A} \mathrm{a}$ & $2.6 \mathrm{~A} \mathrm{a}$ & $3.4 \mathrm{~A} \mathrm{a}$ & $730.2 \mathrm{Ab}$ & $978.2 \mathrm{~A} \mathrm{a}$ \\
\hline $30-000-000000$ & $11.9 \mathrm{~B} \mathrm{a}$ & $12.0 \mathrm{~B} \mathrm{a}$ & $1.3 \mathrm{~B} \mathrm{a}$ & $1.5 \mathrm{C} \mathrm{a}$ & $239.4 \mathrm{C} \mathrm{a}$ & $229.7 \mathrm{C} \mathrm{a}$ \\
\hline $30-150-300-300$ & $13.2 \mathrm{~B} \mathrm{a}$ & $14.2 \mathrm{~A} \mathrm{a}$ & $3.3 \mathrm{~A} \mathrm{a}$ & $3.7 \mathrm{~A} \mathrm{a}$ & $421.0 \mathrm{~B} \mathrm{a}$ & $548.4 \mathrm{~B} \mathrm{a}$ \\
\hline $30-150-300-600$ & $13.8 \mathrm{~B} \mathrm{a}$ & $15.3 \mathrm{~A} \mathrm{a}$ & $2.9 \mathrm{~A} \mathrm{a}$ & $3.2 \mathrm{~A} \mathrm{a}$ & $484.6 \mathrm{~B} \mathrm{~b}$ & $668.1 \mathrm{~B} \mathrm{a}$ \\
\hline $60-000-000-000$ & $12.1 \mathrm{~B} \mathrm{a}$ & $11.1 \mathrm{~B} \mathrm{a}$ & $1.5 \mathrm{~B} \mathrm{a}$ & $1.3 \mathrm{C} \mathrm{a}$ & $204.6 \mathrm{C}$ a & $211.5 \mathrm{C} \mathrm{a}$ \\
\hline $60-000-300-300$ & $14.2 \mathrm{~B} \mathrm{a}$ & $10.9 \mathrm{~B} \mathrm{a}$ & $2.6 \mathrm{Aa}$ & $2.4 \mathrm{~B} \mathrm{a}$ & $234.9 \mathrm{C} \mathrm{a}$ & $305.1 \mathrm{C} \mathrm{a}$ \\
\hline $60-000-300-600$ & $11.9 \mathrm{~B} \mathrm{a}$ & $10.9 \mathrm{~B} \mathrm{a}$ & $2.2 \mathrm{~B} \mathrm{a}$ & $2.2 \mathrm{~B} \mathrm{a}$ & $275.2 \mathrm{C} \mathrm{a}$ & $305.1 \mathrm{C} \mathrm{a}$ \\
\hline $90-000-000-000$ & $13.1 \mathrm{~B} \mathrm{a}$ & $11.8 \mathrm{~B} \mathrm{a}$ & $1.4 \mathrm{~B} \mathrm{a}$ & $1.4 \mathrm{C} \mathrm{a}$ & $182.3 \mathrm{C}$ a & $230.6 \mathrm{C} \mathrm{a}$ \\
\hline $90-000-000-300$ & $13.6 \mathrm{~B} \mathrm{a}$ & $13.5 \mathrm{~B} \mathrm{a}$ & $1.4 \mathrm{~B} \mathrm{a}$ & $1.4 \mathrm{C} \mathrm{a}$ & $184.8 \mathrm{C} \mathrm{a}$ & $270.0 \mathrm{C} \mathrm{a}$ \\
\hline $90-000-000-600$ & $12.2 \mathrm{~B} \mathrm{a}$ & $12.5 \mathrm{~B} \mathrm{a}$ & $1.3 \mathrm{~B} \mathrm{a}$ & $1.1 \mathrm{C} \mathrm{a}$ & $212.2 \mathrm{C} \mathrm{a}$ & $284.8 \mathrm{C}$ a \\
\hline Mean & 13.3 & 14.9 & 2.0 & 2.2 & 341.1 & 429.3 \\
\hline CV (\%) & & & & & & \\
\hline $\mathrm{p}$-value & & & & & & \\
\hline
\end{tabular}

Table 1. Concentrations of macronutrients ( $\mathrm{N}$ and $\mathrm{S}$ ) and micronutrient (Mn) in cladodes of 'Gigante' cactus pear cultivated at different planting configurations and fertilizations

* $\left(\mathrm{Mg} \mathrm{ha}^{-1}\right)$ of manure $-\mathrm{N}\left(\mathrm{kg} \mathrm{ha}^{-1}\right)-\mathrm{P}_{2} \mathrm{O}_{5}\left(\mathrm{~kg} \mathrm{ha}^{-1}\right)-\mathrm{K}_{2} \mathrm{O}\left(\mathrm{kg} \mathrm{ha}^{-1}\right)$; Means followed by the same letters, uppercase in the columns, for fertilization, belong to the same group by the Scott-Knott test $(\mathrm{p} \leq 0.05)$, and lowercase in the rows, for planting configurations, do not differ by $\mathrm{F}$ test at $\mathrm{p} \leq 0.05$ 
$\mathrm{K}_{2} \mathrm{O}$. At the dose 0 , in organic and organomineral fertilizations without addition of $\mathrm{N}$ the concentrations varied from 10.9 to $14.1 \mathrm{~g} \mathrm{~kg}^{-1}$, interpreted as marginal or at the lower limit of the sufficient class (Donato et al., 2017), but within the sufficiency range ( 8.0 to $20.0 \mathrm{~g} \mathrm{~kg}^{-1}$ ) indicated by Blanco-Macías et al. (2010), and were closer to those found by Donato et al. (2016), 11.8 to $14.3 \mathrm{~g} \mathrm{~kg}^{-1}$, with organic fertilization. This is justifiable because the fertilization with $\mathrm{N}$ from organic source has low rates of mineralization and release of mineral $\mathrm{N}$ compared to the mineral source, although the contribution of $\mathrm{N}$ is basically the same at the highest doses, $390 \mathrm{~kg} \mathrm{ha}^{-1}$ of $\mathrm{N}$ for $90 \mathrm{Mg} \mathrm{ha}^{-1}$ of manure, against $300 \mathrm{~kg} \mathrm{ha}^{-1}$ of mineral $\mathrm{N}$.

For the $S$ concentration between fertilizations, two and three groups were formed by the Scott-Knott test ( $p \leq 0.05)$ in the triple- and quadruple-row configurations, respectively. The highest and intermediate values observed in the mineral and organomineral fertilizations, 2.6 to $3.9 \mathrm{~g} \mathrm{~kg}^{-1}$ of $\mathrm{S}$, are above the sufficiency range (1.1-1.9 $\mathrm{g} \mathrm{kg}^{-1}$ ) conforme Donato et al. (2017) and corroborate those of Silva et al. (2012). The use of ammonium sulfate and single superphosphate justifies these results. On the other hand, lower values were found in organic fertilization, 1.1 to $1.5 \mathrm{~g} \mathrm{~kg}^{-1}$, agreeing with Donato et al. (2016) and within the sufficiency range, whereas in the absence of fertilization the values were below the range. Between planting configurations, differences were observed only in mineral fertilizations for S and $\mathrm{Mn}$.

The fertilizations allowed the formation of three groups by the Scott-Knott test ( $\mathrm{p} \leq 0.05)$ for Mn concentration under both planting configurations. The highest and intermediate values, observed under mineral and organomineral fertilizations with $\mathrm{N}$, respectively, range from 421.0 to $978.2 \mathrm{mg} \mathrm{kg}^{-1}$ of $\mathrm{Mn}$, agree with those of Silva et al. (2012) and are above the sufficiency range, 260.0-507.7 $\mathrm{mg} \mathrm{kg}^{-1}$ (Donato et al., 2017) for mineral fertilizations and within the range for organomineral fertilizations. The lowest Mn concentrations were observed under organic fertilization, organomineral fertilization without $\mathrm{N}$ and in the absence of fertilizer. These results agree with those of Nascimento et al. (2002), who claim that soil pH is the factor that most influences $\mathrm{Mn}$ availability for plants. Silva et al. (2012) found Mn concentration of 2,006.0 $\mathrm{mg} \mathrm{kg}^{-1}$, above the sufficiency range, caused by the use of ammonium sulfate as a source of $\mathrm{N}$, which reduces the $\mathrm{pH}$ and thus increases the solubility and absorption of $\mathrm{Mn}^{2+}$, confirmed by the $\mathrm{pH}$ reduction from 5.3 before planting to 4.3 at harvest. On the other hand, Donato et al. (2016) justified the lowest $\mathrm{Mn}$ concentrations in the cladodes with the increment in $\mathrm{pH}$ from 5.4 before planting to $6.0,6.1$ and 6.2 with the additions of 30,60 and $90 \mathrm{Mg} \mathrm{ha}^{-1}$ year $^{-1}$ of manure, respectively, which corroborates with Abreu et al. (2007), who report that Mn availability in the soil is regulated by $\mathrm{pH}$ and organic matter concentration, among others.

In the second cycle for $\mathrm{S}$ concentrations, two groups were formed by the Scott-Knott test at the three spacings (Table 2). The highest values, 1.0 and $3.2 \mathrm{~g} \mathrm{~kg}^{-1}$, were recorded under organomineral and mineral fertilization with N-P-K or with $\mathrm{P}-\mathrm{K}$, being above the sufficiency range (Donato et al., 2017) and agreeing with Silva et al. (2012). The use of ammonium sulfate and single superphosphate justifies these results. The lowest values were found under organic fertilization and in the
Table 2. Concentrations of sulfur (S) in cladodes of 'Gigante' cactus pear cultivated in the second production cycle under different fertilizations and spacings

\begin{tabular}{|c|c|c|c|}
\hline $\begin{array}{c}\text { Cycle II - 2013- } \\
2014\end{array}$ & \multicolumn{3}{|c|}{$S\left(g_{k g}^{-1}\right)$} \\
\hline \multirow[b]{2}{*}{ Fertilizations } & \multicolumn{3}{|c|}{ Spacings } \\
\hline & $\begin{array}{c}S_{1}-3.0 \times 1.0 \times \\
0.25 \mathrm{~m}\end{array}$ & $\begin{array}{c}S_{2}-3.0 \times 1.0 \times \\
0.16 \mathrm{~m}\end{array}$ & $\begin{array}{c}\mathrm{S}_{3}-3.0 \times 1.0 \times \\
0.125 \mathrm{~m}\end{array}$ \\
\hline $0-000-000-000^{*}$ & $1.3 \mathrm{~B} \mathrm{a}$ & $1.0 \mathrm{~B} \mathrm{a}$ & $0.8 \mathrm{~B} \mathrm{a}$ \\
\hline $0-300-300-300$ & $2.6 \mathrm{~A} \mathrm{a}$ & $2.9 \mathrm{~A} \mathrm{a}$ & $3.2 \mathrm{~A} \mathrm{a}$ \\
\hline $0-300-300-600$ & $2.5 \mathrm{~A} \mathrm{a}$ & $2.8 \mathrm{~A} \mathrm{a}$ & $3.0 \mathrm{~A} \mathrm{a}$ \\
\hline $30-000-000-000$ & $1.5 \mathrm{~B} \mathrm{a}$ & $1.6 \mathrm{~B} \mathrm{a}$ & $1.4 \mathrm{~B} \mathrm{a}$ \\
\hline $30-150-300-300$ & $2.4 \mathrm{~A} \mathrm{a}$ & $2.7 \mathrm{~A} \mathrm{a}$ & $3.1 \mathrm{~A} \mathrm{a}$ \\
\hline $30-150-300-600$ & $2.3 \mathrm{~A} \mathrm{a}$ & $2.8 \mathrm{~A} \mathrm{a}$ & $2.8 \mathrm{~A} \mathrm{a}$ \\
\hline $60-000-000-000$ & $1.6 \mathrm{~B} \mathrm{a}$ & $1.5 \mathrm{~B} \mathrm{a}$ & $1.6 \mathrm{~B} \mathrm{a}$ \\
\hline $60-000-300-300$ & $2.0 \mathrm{~A} \mathrm{a}$ & $2.7 \mathrm{~A} \mathrm{a}$ & $2.5 \mathrm{~A} \mathrm{a}$ \\
\hline $60-000-300-600$ & $2.0 \mathrm{~A} \mathrm{a}$ & $2.4 \mathrm{~A} \mathrm{a}$ & $2.3 \mathrm{~A} \mathrm{a}$ \\
\hline $90-000-000-000$ & $1.4 \mathrm{~B} \mathrm{a}$ & $1.7 \mathrm{~B} \mathrm{a}$ & $1.5 \mathrm{~B} \mathrm{a}$ \\
\hline $90-000-000-300$ & $1.5 \mathrm{~B} \mathrm{a}$ & $1.4 \mathrm{~B} \mathrm{a}$ & $1.4 \mathrm{~B} \mathrm{a}$ \\
\hline $90-000-000-600$ & $1.5 \mathrm{~B} \mathrm{a}$ & $1.5 \mathrm{~B} \mathrm{a}$ & $1.6 \mathrm{~B} \mathrm{a}$ \\
\hline Mean & 1.8 & 2.1 & 2.0 \\
\hline CV (\%) & & 17.92 & \\
\hline $\mathrm{p}$-value & & $<0.001$ & \\
\hline
\end{tabular}

${ }^{\star}\left(\mathrm{Mg} \mathrm{ha}^{-1}\right)$ of manure $-\mathrm{N}\left(\mathrm{kg} \mathrm{ha}^{-1}\right)-\mathrm{P}_{2} \mathrm{O}_{5}\left(\mathrm{~kg} \mathrm{ha}^{-1}\right)-\mathrm{K}_{2} \mathrm{O}\left(\mathrm{kg} \mathrm{ha}^{-1}\right) ;$ Means followed by the same letters, uppercase in the columns, for fertilization, belong to the same group by the Scott-Knott test ( $\mathrm{p} \leq 0.05)$, and lowercase in the rows, for planting configurations, do not differ by Tukey test at $\mathrm{p} \leq 0.05$

absence of fertilizer, being below the sufficiency range in the latter for the spacings $S_{2}(3.0 \times 1.0 \times 0.16 \mathrm{~m})$ and $S_{3}(3.0 \times 1.0 \times$ $0.125 \mathrm{~m}$ ). There were no differences between the spacings for any of the fertilizations.

In the second and third production cycles for the $\mathrm{N}$ concentrations, there was the formation of two and three groups by the Scott-Knott test, respectively (Table 3 ). The highest values, 14.3 and $16.0 \mathrm{~g} \mathrm{~kg}^{-1}$, for the second cycle, and 20.3 and $20.9 \mathrm{~g} \mathrm{~kg}^{-1}$ for the third cycle, were recorded under mineral fertilizations with $\mathrm{N}-\mathrm{P}-\mathrm{K}$, being within and above the sufficiency range (Donato et al., 2017), respectively, and agree with Silva et al. (2012).

In general, the lowest values occurred under organic and organomineral fertilizations and absence of fertilizer and agree with Donato et al. (2016). This is justifiable because fertilization with $\mathrm{N}$ from organic source has low rate of mineralization and release of mineral $\mathrm{N}$ compared to the mineral source, for the same contribution of $\mathrm{N}$.

The $\mathrm{P}$ concentration in the cladodes produced in the three production cycles formed four groups by the Scott-Knott test. The highest values, 1.9 to $2.9 \mathrm{~g} \mathrm{~kg}^{-1}$, above the sufficiency range (1.0 to $1.7 \mathrm{~g} \mathrm{~kg}^{-1}$ ) suggested by Donato et al. (2017), were recorded under organomineral fertilization (30-150-300-300 of manure-N-P-K) in the first cycle, mineral fertilization (0-300$300-300 / 600$ of N-P-K) and organomineral fertilization (30$150-300-300 / 600$ of manure-N-P-K) in the second and third cycles, with difference when there was no addition of mineral $\mathrm{N}$ in the organomineral fertilization (60-000-300-300/600 of manure- $\mathrm{N}-\mathrm{P}-\mathrm{K})$. These $\mathrm{P}$ values above the sufficiency range are justified by the initial $\mathrm{P}$ concentration in the soil, $23.57 \mathrm{mg} \mathrm{dm}^{-}$ ${ }^{3}$, within the sufficiency range, 22 to $48 \mathrm{mg} \mathrm{dm}^{-3}$ (Donato et al., 2017) for medium-textured soil and mainly by the fertilizations whose lowest supplies were $300 \mathrm{~kg} \mathrm{ha}^{-1}$ of $\mathrm{P}_{2} \mathrm{O}_{5}$ for mineral fertilization and $270 \mathrm{~kg} \mathrm{ha}^{-1}$ of $\mathrm{P}_{2} \mathrm{O}_{5}$ for organic fertilization with $30 \mathrm{Mg} \mathrm{ha}^{-1}$ of manure. 
Table 3. Concentration of macronutrients and micronutrients in cladodes of 'Gigante' cactus pear subjected to mineral, organomineral and organic fertilizations in three production cycles

\begin{tabular}{|c|c|c|c|c|c|c|c|}
\hline Cycle I - 2011/2013 & \multicolumn{3}{|c|}{ Macronutrients } & \multicolumn{4}{|c|}{ Micronutrients } \\
\hline \multirow{2}{*}{ Fertilizations } & $\mathbf{P}$ & $\mathbf{K}^{+}$ & $\mathrm{Ca}^{2+}$ & $\mathrm{B}^{3-}$ & $\mathrm{Cu}^{2+}$ & $\mathrm{Fe}^{2+}$ & $\mathrm{Zn}^{2+}$ \\
\hline & & $\left(\mathrm{g} \mathrm{kg}^{-1}\right)$ & & \multicolumn{4}{|c|}{$\left(\mathrm{mg} \mathrm{kg} \mathrm{kg}^{-1}\right)$} \\
\hline $0-000-000-000^{*}$ & $0.8 \mathrm{D}$ & $30.7 \mathrm{E}$ & $24.2 \mathrm{~B}$ & $29.4 \mathrm{~B}$ & $1.92 \mathrm{C}$ & $167.8 \mathrm{~B}$ & $37.0 \mathrm{C}$ \\
\hline $0-300-300-300$ & $1.7 \mathrm{~B}$ & $31.1 \mathrm{E}$ & $25.7 \mathrm{~B}$ & $57.4 \mathrm{~A}$ & $2.85 \mathrm{~A}$ & $218.9 \mathrm{~A}$ & $58.4 \mathrm{~B}$ \\
\hline $0-300-300-600$ & $1.6 \mathrm{~B}$ & $34.9 \mathrm{D}$ & $25.8 \mathrm{~B}$ & $58.4 \mathrm{~A}$ & $2.67 \mathrm{~A}$ & $207.1 \mathrm{~A}$ & $54.3 \mathrm{~B}$ \\
\hline $30-000-000-000$ & $1.2 \mathrm{C}$ & $33.6 \mathrm{D}$ & $22.7 \mathrm{~B}$ & $65.0 \mathrm{~A}$ & $2.51 \mathrm{~B}$ & $174.3 \mathrm{C}$ & $69.8 \mathrm{~A}$ \\
\hline $30-150-300-300$ & $2.0 \mathrm{~A}$ & $37.6 \mathrm{C}$ & $28.3 \mathrm{~A}$ & $64.5 \mathrm{~A}$ & $2.88 \mathrm{~A}$ & 191.7 B & $62.3 \mathrm{~B}$ \\
\hline $30-150-300-600$ & $1.8 \mathrm{~B}$ & $40.7 \mathrm{~B}$ & $26.4 \mathrm{~A}$ & $64.4 \mathrm{~A}$ & $2.93 \mathrm{~A}$ & $238.4 \mathrm{~A}$ & $59.5 \mathrm{~B}$ \\
\hline $60-000-000-000$ & $1.3 \mathrm{C}$ & $38.0 \mathrm{C}$ & $25.5 \mathrm{~B}$ & $55.1 \mathrm{~A}$ & $2.43 \mathrm{~B}$ & $181.9 \mathrm{~B}$ & $72.2 \mathrm{~A}$ \\
\hline $60-000-300-300$ & $1.8 \mathrm{~B}$ & $40.7 \mathrm{~B}$ & $27.5 \mathrm{~A}$ & $54.6 \mathrm{~A}$ & $2.51 \mathrm{~B}$ & $241.0 \mathrm{~A}$ & $65.5 \mathrm{~A}$ \\
\hline $60-000-300-600$ & $1.7 \mathrm{~B}$ & $42.6 \mathrm{~A}$ & $28.1 \mathrm{~A}$ & $52.6 \mathrm{~A}$ & $2.37 \mathrm{~B}$ & $205.9 \mathrm{~A}$ & $61.6 \mathrm{~B}$ \\
\hline $90-000-000-000$ & $1.2 \mathrm{C}$ & $40.4 \mathrm{~B}$ & $25.0 \mathrm{~B}$ & $54.1 \mathrm{~A}$ & $2.48 \mathrm{~B}$ & $189.9 \mathrm{~B}$ & $63.4 \mathrm{~B}$ \\
\hline $90-000-000-300$ & $1.3 \mathrm{C}$ & $41.2 \mathrm{~B}$ & $23.8 \mathrm{~B}$ & $58.7 \mathrm{~A}$ & $2.31 \mathrm{~B}$ & $188.6 \mathrm{~B}$ & $68.8 \mathrm{~A}$ \\
\hline $90-000-000-600$ & $1.1 \mathrm{C}$ & $44.0 \mathrm{~A}$ & $24.5 \mathrm{~B}$ & $55.7 \mathrm{~A}$ & $2.15 \mathrm{C}$ & $212.2 \mathrm{~A}$ & $69.6 \mathrm{~A}$ \\
\hline Mean & 1.40 & 37.90 & 25.60 & 55.80 & 2.50 & 201.50 & 61.50 \\
\hline CV (\%) & 16.95 & 11.28 & 15.29 & 35.91 & 21.49 & 34.67 & 26.01 \\
\hline$p$-value & $<0.001$ & $<0.001$ & $<0.001$ & $<0.001$ & $<0.001$ & 0.03 & $<0.001$ \\
\hline Gycle II - 2013-2014 & \multicolumn{5}{|c|}{ Macronutrients } & \multicolumn{2}{|c|}{ Micronutrients } \\
\hline \multirow{2}{*}{ Fertilizations } & $\mathbf{N}$ & $\mathbf{P}$ & $\mathbf{K}^{+}$ & $\mathrm{Ca}^{2+}$ & $\mathrm{Mg}^{2+}$ & $\mathrm{Fe}^{2+}$ & $\mathrm{Mn}^{2+}$ \\
\hline & \multicolumn{5}{|c|}{$\left(\mathrm{g} \mathrm{kg}^{-1}\right)$} & \multicolumn{2}{|c|}{$\left.(\mathrm{mg} \mathrm{kg})^{-1}\right)$} \\
\hline $0-000-000-000^{*}$ & $12.5 \mathrm{~B}$ & $1.0 \mathrm{D}$ & $27.7 \mathrm{D}$ & $31.7 \mathrm{~A}$ & $9.8 \mathrm{~B}$ & $102.9 \mathrm{C}$ & $489.0 \mathrm{~B}$ \\
\hline $0-300-300-300$ & $16.0 \mathrm{~A}$ & $2.9 \mathrm{~A}$ & $32.3 \mathrm{C}$ & $31.4 \mathrm{~A}$ & $9.7 \mathrm{~B}$ & $220.9 \mathrm{~A}$ & $1253.7 \mathrm{~A}$ \\
\hline $0-300-300-600$ & $14.3 \mathrm{~A}$ & $2.8 \mathrm{~A}$ & $37.0 \mathrm{~B}$ & $32.8 \mathrm{~A}$ & $9.3 \mathrm{~B}$ & $185.9 \mathrm{~A}$ & $1364.3 \mathrm{~A}$ \\
\hline $30-000-000-000$ & $12.8 \mathrm{~B}$ & $1.5 \mathrm{C}$ & $37.0 \mathrm{~B}$ & $28.2 \mathrm{~B}$ & $12.3 \mathrm{~A}$ & $160.9 \mathrm{~B}$ & $268.3 \mathrm{C}$ \\
\hline $30-150-300-300$ & $13.1 \mathrm{~B}$ & $2.8 \mathrm{~A}$ & $26.5 \mathrm{~B}$ & $29.6 \mathrm{~B}$ & $10.3 \mathrm{~B}$ & $206.1 \mathrm{~A}$ & $541.5 \mathrm{~B}$ \\
\hline $30-150-300-600$ & $13.3 \mathrm{~B}$ & $2.6 \mathrm{~A}$ & $36.4 \mathrm{~B}$ & $28.6 \mathrm{~B}$ & $10.3 \mathrm{~B}$ & $187.7 \mathrm{~A}$ & 591.7 B \\
\hline $60-000-000-000$ & $12.0 \mathrm{~B}$ & $1.6 \mathrm{C}$ & $37.1 \mathrm{~B}$ & $27.2 \mathrm{C}$ & $12.4 \mathrm{~A}$ & $155.2 \mathrm{~B}$ & $186.9 \mathrm{C}$ \\
\hline $60-000-300-300$ & $12.0 \mathrm{~B}$ & $2.4 \mathrm{~B}$ & $37.2 \mathrm{~B}$ & $29.4 \mathrm{~B}$ & $12.0 \mathrm{~A}$ & $207.8 \mathrm{~A}$ & $216.8 \mathrm{C}$ \\
\hline $60-000-300-600$ & $11.4 \mathrm{~B}$ & $2.2 \mathrm{~B}$ & $42.2 \mathrm{~A}$ & $29.6 \mathrm{~B}$ & $11.9 \mathrm{~A}$ & $205.1 \mathrm{~A}$ & $264.5 \mathrm{C}$ \\
\hline $90-000-000-000$ & $12.9 \mathrm{~B}$ & $1.5 \mathrm{C}$ & $41.0 \mathrm{~A}$ & $25.3 \mathrm{C}$ & $11.7 \mathrm{~A}$ & $246.0 \mathrm{~A}$ & $149.0 \mathrm{C}$ \\
\hline $90-000-000-300$ & $12.5 \mathrm{~B}$ & $1.4 \mathrm{C}$ & $39.4 \mathrm{~A}$ & $22.9 \mathrm{D}$ & $11.5 \mathrm{~A}$ & $217.1 \mathrm{~A}$ & $167.2 \mathrm{C}$ \\
\hline $90-000-000-600$ & $12.4 \mathrm{~B}$ & $1.5 \mathrm{C}$ & $40.7 \mathrm{~A}$ & $24.2 \mathrm{D}$ & $11.0 \mathrm{~A}$ & $252.1 \mathrm{~A}$ & $180.1 C$ \\
\hline Mean & 13.0 & 2.0 & 36.2 & 28.4 & 11.0 & 195.5 & 472.7 \\
\hline CV $(\%)$ & 15.90 & 17.92 & 10.35 & 14.54 & 24.18 & 37.20 & 40.66 \\
\hline$p$-value & $<0.001$ & $<0.001$ & $<0.001$ & $<0.001$ & 0.04 & $<0.001$ & $<0.001$ \\
\hline Cycle III - 2014-2015 & \multicolumn{5}{|c|}{ Macronutrients } & \multicolumn{2}{|c|}{ Micronutrients } \\
\hline \multirow{2}{*}{ Fertilizations } & $\mathbf{N}$ & $\mathbf{P}$ & $\mathrm{K}^{+}$ & $\mathrm{Ca}^{2+}$ & $\mathrm{Mg}^{2+}$ & $\mathrm{Mn}^{2+}$ & $\mathrm{Zn}^{2+}$ \\
\hline & \multicolumn{5}{|c|}{$\left(g_{\mathrm{kg}}^{-1}\right)$} & \multicolumn{2}{|c|}{$\left(\mathrm{mq} \mathrm{kq} q^{-1}\right)$} \\
\hline $0-000-000-000$ * & $14.5 \mathrm{C}$ & 1.2 D & $31.8 \mathrm{C}$ & $33.9 \mathrm{~A}$ & $13.0 \mathrm{~A}$ & $589.4 \mathrm{C}$ & $60.4 \mathrm{C}$ \\
\hline $0-300-300-300$ & $20.9 \mathrm{~A}$ & $2.1 \mathrm{~A}$ & $30.5 \mathrm{C}$ & $31.1 \mathrm{~A}$ & $10.2 B$ & $1984.9 \mathrm{~A}$ & $73.4 \mathrm{~A}$ \\
\hline $0-300-300-600$ & $20.2 \mathrm{~A}$ & $2.0 \mathrm{~A}$ & $36.4 \mathrm{~B}$ & $31.1 \mathrm{~A}$ & $9.5 \mathrm{~B}$ & $2558.3 \mathrm{~A}$ & $71.1 \mathrm{~A}$ \\
\hline $30-000-000-000$ & $14.5 \mathrm{C}$ & $1.5 \mathrm{C}$ & $32.4 \mathrm{C}$ & $28.9 \mathrm{~B}$ & $11.8 \mathrm{~A}$ & $406.3 \mathrm{D}$ & $64.9 \mathrm{~B}$ \\
\hline $30-150-300-300$ & $16.7 \mathrm{~B}$ & $1.8 \mathrm{~B}$ & $34.3 \mathrm{C}$ & $32.8 \mathrm{~A}$ & $11.2 \mathrm{~B}$ & 732.7 B & $60.3 \mathrm{C}$ \\
\hline $30-150-300-600$ & $17.3 \mathrm{~B}$ & $1.7 \mathrm{~B}$ & $37.5 \mathrm{~B}$ & $32.2 \mathrm{~A}$ & $10.4 \mathrm{~B}$ & 950.7 B & $58.4 \mathrm{C}$ \\
\hline $60-000-000-000$ & $15.5 \mathrm{C}$ & $1.6 \mathrm{C}$ & $32.8 \mathrm{C}$ & $25.4 \mathrm{~B}$ & $12.1 \mathrm{~A}$ & $264.1 \mathrm{D}$ & $53.1 \mathrm{D}$ \\
\hline $60-000-300-300$ & $17.2 \mathrm{~B}$ & $2.0 \mathrm{~A}$ & $36.5 \mathrm{~B}$ & $30.3 \mathrm{~A}$ & $12.6 \mathrm{~A}$ & $262.6 \mathrm{D}$ & $53.8 \mathrm{D}$ \\
\hline $60-000-300-600$ & $15.1 \mathrm{C}$ & $1.9 \mathrm{~A}$ & $40.6 \mathrm{~A}$ & $29.9 \mathrm{~A}$ & $11.9 \mathrm{~A}$ & $270.2 \mathrm{D}$ & $54.8 \mathrm{D}$ \\
\hline $90-000-000-000$ & $16.8 \mathrm{~B}$ & $1.8 \mathrm{~B}$ & $37.6 \mathrm{~B}$ & $29.3 \mathrm{~B}$ & $13.6 \mathrm{~A}$ & 187.4 D & $49.9 \mathrm{D}$ \\
\hline $90-000-000-300$ & $15.6 \mathrm{C}$ & $1.7 \mathrm{~B}$ & $38.9 \mathrm{~B}$ & $26.5 \mathrm{~B}$ & $12.8 \mathrm{~A}$ & $137.0 \mathrm{D}$ & $47.9 \mathrm{D}$ \\
\hline $90-000-000-600$ & $14.8 \mathrm{C}$ & $1.7 \mathrm{~B}$ & $42.8 \mathrm{~A}$ & $28.2 \mathrm{~B}$ & $13.2 \mathrm{~A}$ & $154.4 \mathrm{D}$ & $52.5 \mathrm{D}$ \\
\hline Mean & 16.6 & 1.7 & 36.0 & 29.9 & 11.8 & 708.2 & 58.4 \\
\hline CV (\%) & 15.00 & 16.30 & 12.80 & 16.52 & 19.37 & 64.45 & 18.52 \\
\hline $\mathrm{p}$-value & $<0.001$ & $<0.001$ & $<0.001$ & $<0.001$ & $<0.001$ & $<0.001$ & $<0.001$ \\
\hline
\end{tabular}

For the $\mathrm{K}$ concentration in the cladodes, there was the formation of five, four and three groups by the Scott-Knott test for the first, second and third cycles, respectively. The highest $\mathrm{K}$ concentrations were recorded under organomineral fertilizations 60-000-300-600 and 90-000-000-600 ( $\left.\mathrm{Mg} \mathrm{ha}^{-1}\right)$ of manure - N $\left(\mathrm{kg} \mathrm{ha}^{-1}\right)-\mathrm{P}_{2} \mathrm{O}_{5}\left(\mathrm{~kg} \mathrm{ha}^{-1}\right)-\mathrm{K}_{2} \mathrm{O}\left(\mathrm{kg} \mathrm{ha}^{-1}\right)$ for the first and third cycles, and also 90-0000-000-000 and 90-000-000-300 (Mg ha $\left.{ }^{1}\right)$ of manure- $\mathrm{N}\left(\mathrm{kg} \mathrm{ha}^{-1}\right)-\mathrm{P}_{2} \mathrm{O}_{5}\left(\mathrm{~kg} \mathrm{ha}^{-1}\right)-\mathrm{K}_{2} \mathrm{O}\left(\mathrm{kg} \mathrm{ha}^{-1}\right)$ in the second cycle, respectively. In these cases, the $\mathrm{K}$ concentrations ranged from 39.4 to $44 \mathrm{~g} \mathrm{~kg}^{-1}$, remaining within the sufficiency range (31.6-44.1 $\mathrm{g} \mathrm{kg}^{-1}$ ) indicated by Donato et al. (2017). Concentrations below the sufficiency range occurred in the absence of fertilization in the first and second cycles and under the organomineral fertilization 0-300-300-300 $\left(\mathrm{Mg} \mathrm{ha}^{-1}\right)$ of manure-N $\left(\mathrm{kg} \mathrm{ha}^{-1}\right)-\mathrm{P}_{2} \mathrm{O}_{5}\left(\mathrm{~kg} \mathrm{ha}^{-1}\right)-\mathrm{K}_{2} \mathrm{O}\left(\mathrm{kg} \mathrm{ha}^{-1}\right)$ in the second cycle.

The Ca concentrations in the cladodes were higher in the first cycle under organomineral fertilization with N-P-K and P-K, in the absence of fertilization, under the mineral fertilizations in the second cycle, and in all of these in the third cycle. In these cases, the concentrations of Ca ranged from 26.4 to $33.9 \mathrm{~g} \mathrm{~kg}^{-1}$, within 
the sufficiency range for the majority, 23.2-32.8 $\mathrm{g} \mathrm{kg}^{-1}$ (Donato et al., 2017), and agree with Silva et al. (2012). These values are justified by the Ca supplied through single superphosphate and because the $\mathrm{pH}$ value of 5.7 is considered ideal. The lowest values occurred under organic fertilization with higher quantities, as found by Donato et al. (2016), but within the sufficiency range. Organic sources such as manure and sewage effluent are usually poor in Ca (Lemos et al., 2018).

The $\mathrm{Mg}$ concentrations in the cladodes were higher in the second production cycle under organic and organomineral fertilizations with $\mathrm{P}-\mathrm{K}$ and at least $30 \mathrm{Mg} \mathrm{ha}^{-1}$ of manure, and in the third cycle, and also in the absence of fertilization. In these cases, the values ranged from 11 to $13.6 \mathrm{~g} \mathrm{~kg}^{-1}$, within the sufficiency range of 9.5-14.3 $\mathrm{g} \mathrm{kg}^{-1}$ (Donato et al., 2017), and agreed with Donato et al. (2016) and Silva et al. (2012). The lowest concentrations of $\mathrm{Mg}$ in the cladodes under mineral fertilization with N-P-K and organomineral fertilization with N-P-K are possibly due to the competitive inhibition with the $\mathrm{Mg}^{2+}$ of the $\mathrm{NH}_{4}^{+}$and $\mathrm{K}^{+}$applied. Despite this, in all cases, the concentrations of $\mathrm{Mg}^{2+}$ in the cladodes were within the sufficiency range.

The $\mathrm{B}$ concentrations in the cladodes in the first production cycle were higher in the fertilized plants, regardless of the formulation or type of fertilizer used, being statistically lower than those found in plants cultivated in the absence of fertilization. The concentrations ranged from 52.6 to $65 \mathrm{mg} \mathrm{kg}^{-1}$, remaining far above the sufficiency range, 22.3-32.7 $\mathrm{mg} \mathrm{kg}^{-1}$ (Donato et al., 2017) and much higher than those observed by Silva et al. (2012) with mineral fertilization. In the absence of fertilization, the B concentration in the cladodes $\left(29.4 \mathrm{mg} \mathrm{kg}^{-1}\right)$ was within the sufficiency range. The applications of $B$ in the soil, in all treatments and cycles, justify the absence of concentrations of this micronutrient below the sufficiency range.

The $\mathrm{Cu}$ concentration in the cladodes were higher, 2.67 to $2.93 \mathrm{mg} \mathrm{kg}^{-1}$, under the mineral and organomineral fertilizations with $\mathrm{N}-\mathrm{P}-\mathrm{K}$, in the first production cycle. The lowest $\mathrm{Cu}$ concentrations occurred in the plants grown in soil without fertilization and under fertilization with 90-000-000-600 (Mg ha $\left.{ }^{1}\right)$ of manure- $\mathrm{N}\left(\mathrm{kg} \mathrm{ha}^{-1}\right)-\mathrm{P}_{2} \mathrm{O}_{5}\left(\mathrm{~kg} \mathrm{ha}^{-1}\right)-\mathrm{K}_{2} \mathrm{O}\left(\mathrm{kg} \mathrm{ha}^{-1}\right)$. All values were within the sufficiency range, 2.0 to $3.7 \mathrm{mg} \mathrm{kg}^{-1}$ (Donato et al., 2017). $\mathrm{Cu}$ is strongly adsorbed by soil organic matter and interacts with organic compounds, forming stable complexes with carboxylic and phenolic groups (Abreu et al., 2007). This justifies the lowest values under the organic fertilizations.

The Fe concentrations in the cladodes ranged from 185.9 to $246 \mathrm{mg} \mathrm{kg}^{-1}$ in plants subjected to mineral and organomineral fertilizations with N-P-K and P-K in the first production cycle and, besides these, under organomineral fertilizations with $\mathrm{K}$ and organic fertilization with $90 \mathrm{Mg} \mathrm{ha}^{-1}$ of manure, in the second production cycle. The lowest concentration in the second cycle was observed in the absence of fertilization, but all values were above the sufficiency range, $(61.1$ to $126.6 \mathrm{mg}$ $\mathrm{kg}^{-1}$ ) according to Donato et al. (2017). Dubeux Júnior et al. (2010) and Silva et al. (2012) found Fe concentrations in the cladodes much lower than those of the present study.

The $\mathrm{Mn}^{2+}$ concentrations in the cladodes in the second and third production cycles were higher in plants that received mineral fertilization. The values ranged from 1253.7 to 2558.3 $\mathrm{mg} \mathrm{kg}^{-1}$, far above the sufficiency range (260.0-507.7 $\mathrm{mg} \mathrm{kg}$ $\left.{ }^{1}\right)$ suggested by Donato et al. (2017), and agree with Silva et al. (2012), whereas the lowest values recorded under organic fertilizations were below the sufficiency range. Silva et al. (2012) argue that soil $\mathrm{pH}$ is the factor that most influences $\mathrm{Mn}$ availability for plants, and the use of ammonium sulfate, as in the present study, promotes reduction of $\mathrm{pH}$ in the environment, which increases the solubility and consequent absorption of $\mathrm{Mn}^{2+}$ by plants. This justifies the higher values found under mineral fertilization, mainly with greater supply of $\mathrm{N}$.

The $\mathrm{Zn}$ concentrations in the cladodes were higher in the first cycle under organic and organomineral fertilization with $\mathrm{P}-\mathrm{K}$ and $\mathrm{K}$ in the first production cycle and under mineral fertilization in the third production cycle. In these cases, the concentrations ranged from 65.5 to $73.4 \mathrm{mg} \mathrm{kg}^{-1}$, above the ideal range (34.5-57.8 $\mathrm{mg} \mathrm{kg}^{-1}$ ) reported by Donato et al. (2017). The applications of $\mathrm{Zn}$ in the soil, in all treatments and cycles, justify the adequate concentrations of this micronutrient.

The lowest dry matter yields (DMY) of 'Gigante' cactus pear were recorded in the absence of fertilization and with $30 \mathrm{Mg}$ ha $^{-1}$ of manure in most cases (Table 4). The highest values of DMY occurred in treatments under fertilization with greater supply of nutrients, particularly under organic fertilization with $60 \mathrm{Mg} \mathrm{ha}^{-1}$ associated with 300 or $600 \mathrm{~kg} \mathrm{ha}^{-1}$ of $\mathrm{K}_{2} \mathrm{O}, 90 \mathrm{Mg}$ $\mathrm{ha}^{-1}$ of manure with or without supply of $\mathrm{K}$, mineral fertilization with 300-300-600 kg ha-1 of N- $\mathrm{P}_{2} \mathrm{O}_{5}-\mathrm{K}_{2} \mathrm{O}$, or organomineral fertilization with $30 \mathrm{Mg} \mathrm{ha}^{-1}$ of manure and 150-300-600 kg $\mathrm{ha}^{-1}$ of $\mathrm{N}-\mathrm{P}_{2} \mathrm{O}_{5}-\mathrm{K}_{2} \mathrm{O}$. The highest increments of DMY, 35.31 and $45.25 \%$, from the first to the second cycle and from the first to the third cycle, respectively, occurred with $90 \mathrm{Mg} \mathrm{ha}^{-1}$ of manure with or without addition of $\mathrm{K}$.

The present study tried to relate the nutritional efficiency expressed by the coefficient of biological utilization of nutrients $\left(\mathrm{BUC}_{\mathrm{Nui}}\right)$ in cactus pear with mineral, organomineral and organic fertilizations and its association with DMY. According to Silva et al. (2009), the BUC ${ }_{\mathrm{Nui}}$ can be influenced by edaphoclimatic, biological and management factors, which makes it difficult to establish relationships that effectively explain its values in different situations.

In the first production cycle, the macronutrients with highest variation of BUC in response to the fertilizations were $\mathrm{S}, \mathrm{P}, \mathrm{K}$ and $\mathrm{N}$, with formation of four, three, three and two groups, respectively, by the Scott-Knott test. In the second cycle, $\mathrm{K}$ with four, $\mathrm{S}$ and $\mathrm{P}$ with three, $\mathrm{N}, \mathrm{Ca}$ and $\mathrm{Mg}$ with two groups; and in the third production cycle, $\mathrm{S}, \mathrm{P}, \mathrm{K}$ and $\mathrm{N}$ with three, $\mathrm{Ca}$ and $\mathrm{Mg}$ with two groups. This denotes that $\mathrm{S}, \mathrm{K}, \mathrm{P}$ and $\mathrm{N}$, in this order, were the macronutrients whose nutritional efficiency was more sensitive to the fertilizations.

In general, the highest nutritional efficiency occurred in the absence of fertilization for most nutrients. For N, S and P, the organic or organomineral fertilization with greater supply of these nutrients and with higher DMY allowed the expression of higher nutritional efficiency by the cactus pear, whereas for $\mathrm{K}$, higher nutritional efficiency was shown by plants that received mineral fertilization, without association with DMY.

For the micronutrients, the BUC values with the highest variation as a function of the fertilizations were those of $\mathrm{Mn}$, with the formation of four groups, and $\mathrm{Zn}$, with two groups, by the Scott-Knott test in the three production cycles, followed by $\mathrm{B}$ with two groups in the first two cycles and $\mathrm{Cu}$ only in the first cycle. From these results, it can be stated that Mn, Zn and $\mathrm{B}$, in this order, were the micronutrients whose nutritional efficiency was more sensitive to the fertilizations. 
Table 4. Mean values of dry matter yield (DMY) and biological utilization coefficient $\left(\mathrm{BUC}_{\mathrm{Nui}}\right)$ of nutrients in cladodes of 'Gigante' cactus pear subjected to mineral, organomineral and organic fertilization in three production cycles

\begin{tabular}{|c|c|c|c|c|c|c|c|c|c|c|c|c|}
\hline \multirow{4}{*}{ Fertilizations } & \multicolumn{12}{|c|}{ Cycle I - 2011-2013 } \\
\hline & \multicolumn{7}{|c|}{ Macronutrients } & \multicolumn{5}{|c|}{ Micronutrients } \\
\hline & \multirow{2}{*}{$\begin{array}{c}\text { DMY } \\
\left(\mathrm{Mg} \mathrm{ha}^{-1}\right)\end{array}$} & $\overline{B U C_{N}}$ & $\overline{B U C_{P}}$ & $\mathrm{BUC}_{\mathrm{K}}$ & $\mathrm{BUC}_{\mathrm{Ca}}$ & $\mathrm{BUC}_{\mathrm{Mq}}$ & $\overline{\mathrm{BUC}_{\mathrm{s}}}$ & $\overline{\mathrm{BUC}_{\mathrm{B}}}$ & $\overline{\mathbf{B U C}_{\text {си }}}$ & $\overline{B U C_{\mathrm{Fe}}}$ & $\overline{B U C_{M n}}$ & $\overline{\mathrm{BUC}_{\mathrm{Zn}}}$ \\
\hline & & \multicolumn{11}{|c|}{$\left.\mathrm{kg}^{-1}\right)$} \\
\hline $0-000-000-000^{*}$ & $9.3 \mathrm{C}$ & $82.6 \mathrm{~A}$ & $1293.2 \mathrm{~A}$ & $33.4 \mathrm{~A}$ & 43.3 & 123.4 & $1182.1 \mathrm{~A}$ & $41635.9 \mathrm{~A}$ & $879550.8 \mathrm{~A}$ & 6674.5 & $4945.5 \mathrm{~A}$ & $3623.5 \mathrm{~A}$ \\
\hline $0-300-300-300$ & $16.2 \mathrm{~A}$ & $59.8 \mathrm{~B}$ & $583.0 \mathrm{C}$ & $33.0 \mathrm{~A}$ & 41.6 & 131.9 & $291.7 \mathrm{D}$ & $20453.8 \mathrm{~A}$ & $409790.8 \mathrm{~B}$ & 5125.3 & $1358.7 \mathrm{D}$ & $0040.6 \mathrm{~B}$ \\
\hline $0-300-300-600$ & $16.7 \mathrm{~A}$ & $70.4 \mathrm{~B}$ & $661.8 \mathrm{C}$ & $29.7 \mathrm{~B}$ & 40.5 & 149.3 & $361.7 \mathrm{D}$ & 21397.4 B & $512379.8 \mathrm{~B}$ & 5147.5 & $1444.2 \mathrm{D}$ & $21489.7 \mathrm{~B}$ \\
\hline $30-000-000-000$ & $12.4 \mathrm{~B}$ & $86.6 \mathrm{~A}$ & 884.2 B & $30.3 \mathrm{~B}$ & 46.0 & 120.5 & $772.3 \mathrm{~B}$ & $18311.8 \mathrm{~B}$ & $508072.5 \mathrm{~B}$ & 6578.6 & $4632.5 \mathrm{~A}$ & $18248.0 \mathrm{~B}$ \\
\hline $30-150-300-300$ & $15.8 \mathrm{~A}$ & $78.3 \mathrm{~A}$ & $533.0 \mathrm{C}$ & $27.5 \mathrm{C}$ & 38.8 & 126.3 & $296.4 \mathrm{D}$ & $17514.7 \mathrm{~B}$ & $422686.1 \mathrm{~B}$ & 5751.8 & $2500.8 \mathrm{C}$ & $19233.0 \mathrm{~B}$ \\
\hline $30-150-300-600$ & $15.6 \mathrm{~A}$ & $70.6 \mathrm{~B}$ & 579.2 C & $25.2 \mathrm{C}$ & 39.7 & 124.9 & $338.6 \mathrm{D}$ & $17602.5 \mathrm{~B}$ & $397480.7 \mathrm{~B}$ & 4853.0 & $1883.9 \mathrm{D}$ & $19820.2 \mathrm{~B}$ \\
\hline $60-000-000-000$ & $14.5 \mathrm{~A}$ & $90.9 \mathrm{~A}$ & $783.1 \mathrm{~B}$ & $27.0 \mathrm{C}$ & 41.1 & 121.7 & $739.3 \mathrm{~B}$ & 19620.1 B & $496904.5 \mathrm{~B}$ & 6004.3 & $5625.2 \mathrm{~A}$ & 15684.5 B \\
\hline $60-000-3$ & $16.6 \mathrm{~A}$ & $86.4 \mathrm{~A}$ & $568.9 \mathrm{C}$ & $25.3 \mathrm{C}$ & 38.4 & 113.6 & $420.5 \mathrm{C}$ & $19575.3 \mathrm{~B}$ & $482733.4 \mathrm{~B}$ & 5154.4 & $4038.4 \mathrm{~B}$ & $19073.5 \mathrm{~B}$ \\
\hline $60-000-300-600$ & $15.1 \mathrm{~A}$ & $94.6 \mathrm{~A}$ & $604.7 \mathrm{C}$ & $24.2 \mathrm{C}$ & 37.8 & 123.3 & $486.1 \mathrm{C}$ & 19795.4 B & $503766.1 \mathrm{~B}$ & 5843.9 & $34655.7 \mathrm{~B}$ & 18515.3 B \\
\hline $90-0 \mathrm{C}$ & $14.1 \mathrm{~A}$ & $82.4 \mathrm{~A}$ & $835.4 \mathrm{~B}$ & $25.4 \mathrm{C}$ & 42.2 & 106.8 & $741.7 \mathrm{~B}$ & $21470.7 \mathrm{~B}$ & & 6095.5 & & $17404.0 \mathrm{~B}$ \\
\hline $90-000-000-300$ & $15.2 \mathrm{~A}$ & $78.3 \mathrm{~A}$ & $781.4 \mathrm{~B}$ & $24.8 \mathrm{C}$ & 43.4 & 118.4 & $762.3 \mathrm{~B}$ & $18948.0 \mathrm{~B}$ & $544908.7 \mathrm{~B}$ & 5671.3 & $4736.6 \mathrm{~A}$ & $17475.5 \mathrm{~B}$ \\
\hline $90-000-000-600$ & $15.0 \mathrm{~A}$ & $82.4 \mathrm{~A}$ & $902.7 \mathrm{~A}$ & $23.5 \mathrm{C}$ & 43.3 & 120.4 & $852.8 \mathrm{~B}$ & 21104.3 B & $597549.4 \mathrm{~B}$ & 5325.5 & $4517.0 \mathrm{~A}$ & $16613.0 \mathrm{~B}$ \\
\hline Mean & 14.7 & 80.3 & 750.9 & 27.5 & 41.4 & 123.4 & 603.8 & 21452.5 & 521429.1 & 5685.4 & 3682.8 & 19743.4 \\
\hline CV (\%) & 30.02 & 24.57 & 25.78 & 17.52 & 23.69 & 27.77 & 35.96 & 40.30 & 70.59 & 34.03 & 35.58 & 39.24 \\
\hline \multirow[t]{2}{*}{ p-value } & $<0.001$ & $<0.001$ & $<0.001$ & $<0.001$ & 0.351 & 0.091 & $<0.001$ & $<0.001$ & 0.021 & 0.086 & $<0.001$ & $<0.001$ \\
\hline & \multicolumn{12}{|c|}{ || - 2013-2014 } \\
\hline $00 *$ & $7.9 \mathrm{C}$ & $82.3 \mathrm{~A}$ & $91.2 \mathrm{~A}$ & $36.5 \mathrm{~A}$ & $32.6 \mathrm{~B}$ & $110.3 \mathrm{~A}$ & $1001.5 \mathrm{~A}$ & $41225.2 \mathrm{~A}$ & 473150.8 & 12248.6 & $06.3 \mathrm{D}$ & $6.7 \mathrm{~A}$ \\
\hline $0-30$ & $13.5 \mathrm{~B}$ & $64.5 \mathrm{~B}$ & $528.9 \mathrm{C}$ & $31.8 \mathrm{~B}$ & $33.0 \mathrm{~B}$ & $20.6 \mathrm{~A}$ & & $28968.6 \mathrm{~B}$ & 424084.2 & 12598.5 & $897.6 \mathrm{E}$ & $19132.2 \mathrm{~B}$ \\
\hline $0-300-3$ & $12.8 \mathrm{~B}$ & $72.0 \mathrm{~B}$ & $614.4 \mathrm{~B}$ & $27.5 \mathrm{C}$ & $31.3 \mathrm{~B}$ & $120.9 \mathrm{~A}$ & $365.9 \mathrm{C}$ & $30836.9 \mathrm{~B}$ & 369123.9 & 10483.4 & $780.2 \mathrm{E}$ & $18601.5 \mathrm{~B}$ \\
\hline $30-000-0$ & $12.4 \mathrm{~B}$ & $80.8 \mathrm{~A}$ & $624.3 \mathrm{~B}$ & $27.7 \mathrm{C}$ & $36.1 \mathrm{~B}$ & $86.0 \mathrm{~B}$ & $692.3 \mathrm{~B}$ & $32019.2 \mathrm{~B}$ & 469335.3 & 12812.0 & $4341.0 \mathrm{C}$ & 15596.2 B \\
\hline $30-15$ & $15.5 \mathrm{~A}$ & $79.0 \mathrm{~A}$ & $549.1 \mathrm{C}$ & $28.3 \mathrm{C}$ & $35.0 \mathrm{~B}$ & $106.3 \mathrm{~A}$ & $381.2 \mathrm{C}$ & $31983.6 \mathrm{~B}$ & 465522.7 & 12031.6 & $2101.8 \mathrm{D}$ & $17117.8 \mathrm{~B}$ \\
\hline $30-1$ & $13.7 \mathrm{~B}$ & $77.2 \mathrm{~A}$ & $509.1 \mathrm{C}$ & $28.0 \mathrm{C}$ & $36.3 \mathrm{~B}$ & $104.5 \mathrm{~A}$ & $390.0 \mathrm{C}$ & $29576.6 \mathrm{~B}$ & 480782.4 & 12394.3 & $1847.7 \mathrm{D}$ & $18193.5 \mathrm{~B}$ \\
\hline $60-0$ & $12.9 \mathrm{~B}$ & $85.3 \mathrm{~A}$ & $558.9 \mathrm{C}$ & $27.4 \mathrm{C}$ & $37.6 \mathrm{~B}$ & $84.3 \mathrm{~B}$ & $648.9 \mathrm{~B}$ & $33303.2 \mathrm{~B}$ & 403100.8 & 11865.4 & $5828.1 \mathrm{~B}$ & $16610.8 \mathrm{~B}$ \\
\hline $60-0$ & $17.1 \mathrm{~A}$ & $86.6 \mathrm{~A}$ & $515.8 \mathrm{C}$ & $27.2 \mathrm{C}$ & $34.6 \mathrm{~B}$ & $91.0 \mathrm{~B}$ & $432.8 \mathrm{C}$ & $33222.4 \mathrm{~B}$ & 470289.4 & 12006.0 & $5115.4 \mathrm{C}$ & $17493.4 \mathrm{~B}$ \\
\hline $60-00$ & $17.5 \mathrm{~A}$ & $88.9 \mathrm{~A}$ & $514.3 \mathrm{C}$ & $24.1 \mathrm{D}$ & $34.4 \mathrm{~B}$ & $89.0 \mathrm{~B}$ & $475.9 \mathrm{C}$ & 31004.7 B & 447341.2 & 12569.6 & $4155.5 \mathrm{C}$ & 18393.3B \\
\hline $90-0 c$ & $18.7 \mathrm{~A}$ & $78.5 \mathrm{~A}$ & $557.0 \mathrm{C}$ & $24.8 \mathrm{D}$ & $40.8 \mathrm{~A}$ & $92.3 \mathrm{~B}$ & $655.0 \mathrm{~B}$ & 34445.7 B & 434018.1 & 12398.0 & $7190.5 \mathrm{~A}$ & 19976.2 B \\
\hline & $22.0 \mathrm{~A}$ & $83.1 \mathrm{~A}$ & $593.5 \mathrm{~B}$ & $25.6 \mathrm{D}$ & $44.9 \mathrm{~A}$ & $94.2 \mathrm{~B}$ & $692.3 \mathrm{~B}$ & & 428899.9 & 11449.7 & & $19293.6 \mathrm{~B}$ \\
\hline $90-000-000-600$ & $19.4 \mathrm{~A}$ & $83.0 \mathrm{~A}$ & $601.9 \mathrm{~B}$ & $25.0 \mathrm{D}$ & $42.6 \mathrm{~A}$ & $98.3 \mathrm{~B}$ & $654.3 \mathrm{~B}$ & $30014.6 \mathrm{~B}$ & 444902.1 & 11729.2 & $5917.5 \mathrm{~B}$ & $17511.0 \mathrm{~B}$ \\
\hline & 150 & & & 27.8 & 36.6 & 99.8 & & & 442545.9 & 120 & 3908.7 & 18732.2 \\
\hline CV (\%) & 34.02 & 17.82 & 22.98 & 14.92 & 17.65 & 26.62 & 19 & 26.48 & 41.91 & 37.99 & 33.63 & 34.09 \\
\hline \multirow[t]{2}{*}{$p$-value } & $<0.001$ & $<0.001$ & $<0.001$ & $<0.001$ & $<0.001$ & $<0.001$ & $<0.001$ & 0.007 & 0.066 & 0.077 & $<0.001$ & $<0.001$ \\
\hline & \multicolumn{12}{|c|}{ Cycle III - 2014-2015 } \\
\hline $00^{*}$ & $8.2 \mathrm{D}$ & $71.0 \mathrm{~A}$ & A & $32.8 \mathrm{~A}$ & $1.3 \mathrm{~B}$ & $78.6 \mathrm{~B}$ & $774.2 \mathrm{~A}$ & & 342 & & $7 \mathrm{D}$ & $6 \mathrm{~B}$ \\
\hline $0-300$ & $16.6 \mathrm{~B}$ & $49.4 \mathrm{C}$ & $498.4 \mathrm{C}$ & $33.6 \mathrm{~A}$ & $2.8 \mathrm{~B}$ & $101.3 \mathrm{~A}$ & $83.0 \mathrm{C}$ & 39975.9 & 10009.1 & 7686.2 & $1465.2 \mathrm{D}$ & $14959.6 \mathrm{~B}$ \\
\hline $0-3$ & $21.5 \mathrm{~A}$ & $50.4 \mathrm{C}$ & C & $27.8 \mathrm{~B}$ & $33.2 \mathrm{~B}$ & $109.1 \mathrm{~A}$ & & 39492.6 & 322147.9 & .8 & & $9.0 \mathrm{~B}$ \\
\hline $30-0$ & $13.1 \mathrm{C}$ & $70.9 \mathrm{~A}$ & $682.1 \mathrm{~B}$ & $31.4 \mathrm{~A}$ & $35.3 \mathrm{~B}$ & $87.3 \mathrm{~B}$ & B A & 37370.1 & 14480.3 & 1905.8 & $4212.6 \mathrm{C}$ & $16047.3 \mathrm{~B}$ \\
\hline & $\mathrm{P}$ & 6 & & $29.6 \mathrm{~A}$ & & & & & & & & $42.1 \mathrm{~B}$ \\
\hline $30-1$ & $20.4 \mathrm{~A}$ & $59.0 \mathrm{~B}$ & $577.8 \mathrm{C}$ & $27.0 \mathrm{~B}$ & $31.9 \mathrm{~B}$ & $99.6 \mathrm{~A}$ & $367.9 \mathrm{C}$ & 39370.3 & 380210.4 & 16477.3 & $1400.7 \mathrm{D}$ & $18004.5 \mathrm{~B}$ \\
\hline $60-0$ & $17.6 \mathrm{~B}$ & $66.8 \mathrm{~A}$ & $652.7 \mathrm{~B}$ & $32.0 \mathrm{~A}$ & 6 & $85.7 \mathrm{~B}$ & $704.3 \mathrm{~A}$ & 40000.6 & 440594.1 & 20247.9 & $5959.1 \mathrm{~A}$ & $20605.2 \mathrm{~A}$ \\
\hline $60-0$ & $20.5 \mathrm{~A}$ & $59.3 \mathrm{~B}$ & $505.0 \mathrm{C}$ & $27.9 \mathrm{~B}$ & $34.0 \mathrm{~B}$ & $82.8 \mathrm{~B}$ & $486.8 \mathrm{~B}$ & 42141.6 & 445317.9 & 2.0 & & $19864.6 \mathrm{~A}$ \\
\hline-600 & $21.3 \mathrm{~A}$ & $67.0 \mathrm{~A}$ & $545.9 \mathrm{C}$ & $24.9 \mathrm{C}$ & $35.6 \mathrm{~B}$ & $91.1 \mathrm{~B}$ & $493.1 \mathrm{~B}$ & 40060.4 & 383017.1 & 18845.2 & $4273.7 \mathrm{C}$ & $19003.9 \mathrm{~A}$ \\
\hline 90-000-000-000 & $21.1 \mathrm{~A}$ & 61.5 & 570 & $27.0 \mathrm{~B}$ & $35.5 \mathrm{~B}$ & $78.6 \mathrm{~B}$ & $656.7 \mathrm{~A}$ & 42113.9 & & & & $3 \mathrm{~A}$ \\
\hline 300 & $19.9 \mathrm{~A}$ & $66.2 \mathrm{~A}$ & $616.5 \mathrm{C}$ & $26.3 \mathrm{~B}$ & $40.3 \mathrm{~A}$ & $86.7 \mathrm{~B}$ & $745.1 \mathrm{~A}$ & 35574.3 & 452848.6 & 18852.4 & $7467.3 \mathrm{~A}$ & $21772.5 \mathrm{~A}$ \\
\hline $90-000-0$ & $23.3 \mathrm{~A}$ & $70.0 \mathrm{~A}$ & $575.5 \mathrm{C}$ & $23.4 \mathrm{C}$ & $38.0 \mathrm{~A}$ & $77.3 \mathrm{~B}$ & $68.5 \mathrm{~A}$ & 35280.8 & 410956.6 & 128469.4 & $7080.5 \mathrm{~A}$ & $19650.9 \mathrm{~A}$ \\
\hline Mean & 18.5 & 62.8 & 594.1 & 28.6 & 35.5 & 89.3 & 554.3 & 40316.3 & 392693.3 & 20072.3 & 4012.0 & 18422.2 \\
\hline CV (\%) & 27.01 & 17.85 & 21.69 & 16.39 & 833. & 21.58 & 26.93 & 26.10 & 42.62 & 93.57 & 48.78 & 23.57 \\
\hline $\mathrm{p}$-value & $<0.001$ & $<0.001$ & $<0.001$ & $<0.001$ & 0.007 & $<0.001$ & $<0.001$ & 0.128 & 0.166 & 0.219 & $<0.001$ & $<0.001$ \\
\hline
\end{tabular}

Higher values of nutritional efficiency for $\mathrm{Mn}$ in the three cycles and for $\mathrm{Zn}$ in the third cycle in cactus pear were observed under the organic fertilizations that are associated with the highest DMY, whereas the lowest values were found under mineral fertilizations. The lower availability due to the adsorption of these nutrients and to the elevation of pH by the organic fertilizer (Abreu et al., 2007; Donato et al., 2016) contributed to this, as occurred in the absence of fertilization for $\mathrm{Mn}$ in the first cycle and for $\mathrm{Zn}$ in the first two cycles.

On the other hand, the higher availability of Mn due to the acidification of the soil caused by ammonium sulfate in the mineral fertilization (Silva et al., 2012) reduced its nutritional efficiency in 'Gigante' cactus pear.

\section{Conclusions}

1. The nutritional efficiency of N, S, P, Mn and $\mathrm{Zn}$ in 'Gigante' cactus pear is higher with organic and organomineral fertilization and are associated with higher dry matter yields, whereas $\mathrm{K}$ nutritional efficiency is higher with mineral fertilization.

2. Organic fertilization reduces the Mn concentrations in the cladodes to levels below the sufficiency range. 
3. The absence of fertilization or application of $30 \mathrm{Mg} \mathrm{ha}^{-1}$ year $^{-1}$ of bovine manure is insufficient to ensure the nutritional status and dry matter yield above $15 \mathrm{Mg} \mathrm{ha}^{-1}$ in 'Gigante' cactus pear.

\section{Literature Cited}

Abreu, C. A.; Lopes, A. S.; Santos, G. C. G. dos. Micronutrientes. In: Novais, R. F.; Alvarez V, V. H.; Barros, N. F. de; F. Fontes, R. L.; Cantarutti, R. B.; Neves, J. C. L. Fertilidade do solo. Viçosa: Sociedade Brasileira de Ciência do Solo, 2007. Cap. 11, p.645-736.

Alves, J. F. T. Estabelecimento de faixas de suficiência para avaliação nutricional da palma forrageira 'Gigante'. Guanambi: Instituto Federal Baiano, 2017. 57p. Dissertação Mestrado

Blanco-Macías, F.; Magallanes-Quintanar, R.; Valdez-Cepeda, R. D.; Vázquez-Alvarado, R.; Olivares-Sáenz, E.; Gutiérrez-Ornelas, E.; Vidales-Contreras, J. A.; Murillo-Amador, B. Nutritional reference values for Opuntia ficus-indica determined by means of the boundary-line approach. Journal of Plant Nutrition Soil Science, v.173, p.927-934, 2010. https://doi.org/10.1002/jpln.200900147

Brasil. Ministério da Agricultura, Pecuária e Abastecimento. Manual de métodos analíticos oficiais para fertilizantes minerais, orgânicos, organominerais e corretivos. Brasília: MAPA/SDA/ CGAL, 2014. 220p.

Cavalcante, L. A. D.; Santos, G. R de A.; Silva, L. M. da; Fagundes, J. L.; Silva, M. A. da. Respostas de genótipos de palma forrageira a diferentes densidades de cultivo. Pesquisa Agropecuária Tropical, v.44, p.424-433, 2014. https://doi.org/10.1590/S198340632014000400010

Deus, J. A. L. de; Soares, I.; Neves, J. C. L.; Medeiros, J. F. de; Miranda, F. R. de. Fertilizer recommendation system for melon based on nutritional balance. Revista Brasileira de Ciência do Solo, v.39, p.498-511, 2015. https://doi.org/10.1590/01000683rbcs20140172

Donato, P. E. R.; Donato, S. L. R.; Silva, J. A.; Pires, A. J. V.; Raul, C. C.; Rosa, R. C. C.; Aquino, A. A. Nutrition and yield of 'Gigante' cactus pear cultivated with different spacings and organic fertilizer. Revista Brasileira de Engenharia Agrícola e Ambiental, v.20, p.1083-1088, 2016. https://doi.org/10.1590/1807-1929/ agriambi.v20n12p1083-1088

Donato, P. E. R.; Pires, A. J.; Donato, S. L. R.; Bonomo, P.; Silva, J. A.; Aquino, A. A. Morfometria e rendimento da palma forrageira 'Gigante' sob diferentes espaçamentos e doses de adubação orgânica. Revista Brasileira de Ciências Agrárias, v.9, p.151-158, 2014a. https://doi.org/10.5039/agraria.v9i1a3252

Donato, P. E. R.; Pires, A. J. V.; Donato, S. L. R.; Silva, J. A. da; Aquino, A. A. de. Valor nutritivo da palma forrageira 'Gigante' cultivada sob diferentes espaçamentos e doses de esterco bovino. Revista Caatinga, v.27, p.163-172, 2014 b.
Donato, S. L. R.; Donato, P. E. R.; Silva, J. A.; Rodrigues, M. G. V. Diagnóstico nutricional e recomendação de adubação para a palma forrageira 'Gigante’. Informe Agropecuário, v.38, p. 46-58, 2017.

Donato, S. L. R.; Lédo, A. A.; Pereira, M. C. T.; Coelho, E. F.; Cotrim, C. E.; Coelho Filho, M. A. Estado nutricional de bananeiras tipo Prata sob diferentes sistemas de irrigação. Pesquisa Agropecuária. Brasileira, v.45, p.980-988, 2010. http://dx.doi.org/10.1590/S0100204X2010000900007

Dubeux Júnior, J. C. B.; Araújo Filho, J. T.; Santos, M. V. F. dos; Lira, M. A.; Santos, D. C. dos; Pessoa, R. A. S. Adubação mineral no crescimento e composição mineral da palma forrageira - Clone IPA-20. Revista Brasileira de Ciências Agrárias, v.5, p.129-135, 2010. https://doi.org/10.5039/agraria.v5ila591

Lemos, M. de; Ferreira Neto, M.; Medeiros, J. F. de; Dias, N. S. da; Silva, E. F. de F. e; Lira, R. B. de. Nutritional evaluation of forage cactus fertigated with domestic sewage effluent. Revista Caatinga, v.31, p.476-486, 2018. https://doi.org/10.1590/1983$21252018 \mathrm{v} 31 \mathrm{n} 224 \mathrm{rc}$

Malavolta, E.; Vitti, G. C.; Oliveira, S. A. Avaliação do estado nutricional das plantas: Princípios e aplicações. Piracicaba: Associação Brasileira para Pesquisa da Potassa e do Fosfato, 1989. 201p.

Nascimento, C. W. A.; Fontes, R. L. F.; Neves, J. C. L. Dessorção, extração e fracionamento de manganês em Latossolos. Revista Brasileira de Ciência do Solo, v.26, p.589-597, 2002. https://doi. org/10.1590/S0100-06832002000300003

Silva, A. P. da; Alvarez V., V. H.; Souza, A. P. de; Neves, J. C. L.; Novais, R. F.; Dantas, J. P. Sistema de recomendação de fertilizantes e corretivos para a cultura do abacaxi - Fertcalc-abacaxi. Revista Brasileira de Ciência do Solo, v.33, p.1269-1280, 2009. https://doi. org/10.1590/S0100-06832009000500020

Silva, J. A.; Bonomo, P.; Donato, S. L. R.; Pires, A. J. V.; Rosa, R. C. C.; Donato, P. E. R. Composição mineral de palma forrageira sob diferentes espaçamentos e adubações química. Revista Brasileira de Ciências Agrárias, v.7, p.866-875, 2012. https://doi. org/10.5039/agraria.v7isa2134

Silva, J. A.; Bonomo, P.; Donato, S. L. R.; Pires, A. J. V.; Silva, F. F.; Donato, P. E. R. Composição bromatológica de cladódios de palma forrageira sob diferentes espaçamentos e adubações química. Revista Brasileira de Ciências Agrárias, v.8, p.342-350, 2013. http://dx.doi.org/10.5039/agraria.v8i2a2431

Silva, L. M. da; Fagundes, J. L.; Viegas, P. A. A.; Muniz, E. N.; Rangel, J. H. de A.; Backes, A. A. Produtividade da palma forrageira cultivada em diferentes densidades de plantio. Ciência Rural, v.44, p.2064-2071, 2014. https://doi.org/10.1590/0103$8478 \mathrm{cr} 20131305$ 